secretary (physical and industrial sciences); Mr. W. Ives, secretary (agricultural and biological sciences); and Mr. M. G. Grace, secretary (finance and supplies).

\section{Agricultural Census in Iraq}

THE first agricultural census to be undertaken in the Middle East is now nearing completion in Iraq. This census, organized and directed by Dr. K. G. Fenelon, who is Government statistician, will provide information much needed for the planning of developments made possible by the rapidly increasing revenues from oil royalties. The statistics now being collected relate to such matters as land utilization, land tenures, farm labour, size of farms, erops and the livestock carried on farms or owned by nomadic tribes. Special emphasis has been placed on the need for early publication, and already data for certain districts are available. The census is a nation-wide survey and has necessitated a farm-to-farm visitation by specially trained enumerators drawn largely from the ranks of teachers and college students on vacation. As the majority of the farmers are illiterate, the verbal information given by them has had to be entered on the forms by the enumerators themselves and, where necessary, translated into Arabic from Kurdish or Turkish. In taking the census, which began in June and is expected to be completed in November, many difficulties have had to be overcome, especially in those districts where land settlement is not yet completed or where the flocks of nomadic tribes have to be enumerated. Many of the farms and villages are far removed from any main road, and though motor transport has been used where possible, other means of transit, such as mules in the mountains, camels in the desert or small boats in the marsh-lands, have been employed to reach these more remote villages.

\section{Nuffield Botanic Garden, London}

WHEN the Nuffield Foundation moves into its new headquarters at Grove House, Regent's Park, London, a large part of the four acres of gardens in which the house stands will be made available by the Foundation to University College, University of London, for botanical research. The garden will be known as the "Nuffield Botanic Garden". In the first instance, research is envisaged which will deal with some of the genetical aspects of the taxonomy of native British species and also with the problems associated with intersexes in plants, under the direction of Dr. J. Heslop Harrison. It is expected that later developments may include both ecological and experimental studies of native species, particularly those of taxonomic and ecological interest. Botanists will note with appreciation this important extension of the interests of the Nuffield Foundation to the field of experimental taxonomy.

\section{Television in Wales and Scotland}

ON August 15, the Postmaster-General, Lord De La Warr, opened the new television transmitting station for South Wales at Wenvoe, near Cardiff, thereby completing the first stage of the installation of the British television network. At the present time, this station is operating with a $5-\mathrm{kW}$. transmitter, but it will be raised to at least ten times this rating as soon as possible. Two days later, the Scottish station at Kirk o' Shotts was brought into full high-power operation by the completion of the new vision transmitter supplied by Electric and Musical Industries, Ltd., which is capable of delivering $75 \mathrm{~kW}$. into the aerial. The corresponding high-power sound transmitter, supplied by Standard Telephones and Cables, Ltd., has a carrier output of $18 \mathrm{~kW}$. at 100 per cent modulation. These installations replace the lowpower standby transmitters which have been in use since the Scottish television service was opened last March (see Nature, March 22, p. 482). When the corresponding high-power transmitters are completed at Wenvoe, Scotland and Wales (including the west of England) will have the most powerful television stations in Britain and, it is thought, in the world. The completion of these stations will bring the British television service within the reach of some 40 million people, or about four-fifths of the population of the United Kingdom.

\section{Social Insurance and the Problems of Poverty}

THE Beveridge report on social insurance and allied services in Great Britain defined freedom from want as the basic purpose of the social security scheme. A recent broadsheet issued by Political and Economic Planning (No. 344. "Poverty: 'Ten Years After Beveridge") examines the extent to which efficient and permanent defences against poverty have been built up in Britain in fulfilment of this purpose during the past ten years. Attention is focused principally on the information and methods avajlable for giving a definite meaning to poverty and thus fixing a poverty standard which can be used both by investigators in charge of social surveys and by administrators in determining the level of social payments. In particular, an attempt is made to give a clearer meaning to the term 'subsistence minimum' and to indicate the steps involved in arriving at such a minimum. At present, insufficient information is available to enable a. satisfactory subsistence standard to be worked out, although the proposed inquiry of the Ministry of Labour into family budgets, intended to supply facts for a revision of the index of retail prices, could supply much of the missing information. The use of family budget data is the only practical way, the broadsheet points out, of limiting the arbitrariness of judgments for items other than food, and there is a strong argument for adding a few specific items, such as postage, shaving and hairdressing, laundry, contraceptives, sanitary towels, certain subscriptions, soap and other cleaning materials, to the list of necessities usually adopted in a standard, on the ground both that they occupy a consistent place in family budgets and that 'by conventional standards' they are necessities. In the last resort, decisions must be based on contemporary views about the lowest living conditions that are tolerable in the community. Whatever policy of preventing poverty is adopted, a carefully determined subsistence standard is essential for its success.

\section{Sociological Bulletin}

The first issue of the new journal of the Indian Sociological Society, entitled the Sociological Bulletin (1, No. 1 ; 1952. Pp. 88 ; from the Indian Sociological Society, Jamnalal Bajaj Nagar, Kurla Road, Andheri ; Rs. 3, or 4s.), is given a characteristic flavour of its own by the essay it includes by Prof. D. P. Mukerji on "Sociology in Independent India". The subject has, he thinks, been ignored hitherto by the Government of India, and insufficient use has been made of sociologists in the drafting of legislation. Nevertheless, sociology can now be offered in the competitive examinations of the Union Public Service Commission, which will give it a new status. Still 